\title{
MENGAJAR MATEMATIKA TRIGONOMETRI DAN PENERAPANNYA DALAM KEHIDUPAN SEHARI-HARI DI SMA TARAKANITA CITRA RAYA
}

\author{
Tri Sutrisno ${ }^{1}$, Muhammad Choirul Imam $^{2}$, Michael Nathan $^{3}$ dan Luthfi Arifandi ${ }^{4}$ \\ ${ }^{1}$ Program Studi Sistem Informasi, Universitas Tarumanagara \\ Email:tris@fti.untar.ac.id \\ ${ }^{2}$ Program Studi Sistem Informasi, Universitas Tarumanagara \\ Email:muhammad.825190105@stu.untar.ac.id \\ ${ }^{3}$ Program Studi Teknik Informatika, Universitas Tarumanagara \\ Email: michael.535190003@stu.untar.ac.id \\ ${ }^{4}$ Program Studi Teknik Elektro, Universitas Tarumanagara \\ Email: luthfi.525190014@stu.untar.ac.id
}

\begin{abstract}
The Covid-19 pandemic has changed the world of education, the learning process in schools cannot be carried out, everything has turned to distance learning, face-to-face interactions have turned virtual, learning tools and media rely on technology. When a pandemic condition occurs for a long time, boredom and fatigue can no longer be avoided, then motivation and enthusiasm for learning become the main concern. Therefore, SMA Tarakanita Citra Raya seeks to present a different learning experience from the usual by creating a "Guest Teacher" program, one of which is inviting lecturers to teach. Mathematics is a subject that is not liked by most students, this happens also at SMA Tarakanita Citra Raya for mathematics subjects, especially on the subject of Trigonometry. Therefore, problem solving is done by offering community service by teaching mathematics. This activity aims to provide new experiences for students and make students more interested in learning mathematics, especially Trigonometry. The method used is Brain Based Learning which is emphasized at the Student Center and provides an explanation of the basic concepts of the origin of trigonometric formulas and their application in daily life in various fields of disciplines so that students become more interested, students' motivation to learn is increasing. This is shown by the large number of participants who exceed the zoom capacity, so that at the beginning of the event, there were a few technical problems. However, overall the planned program was carried out smoothly. In addition to students being more interested, students' reasoning and thinking processes are increasing. This is indicated by the number of students who are enthusiastic about asking questions and conveying their experience findings that are in accordance with the implementation of trigonometric concepts.
\end{abstract}

Keywords: teaching, mathematics, trigonometry and its applications

\begin{abstract}
ABSTRAK
Pandemi Covid 19 telah mengubah dunia Pendidikan, proses pembelajaran di sekolah tidak dapat dilaksanakan, semua beralih ke pembelajaran jarak jauh, interaksi tatap muka berubah menjadi virtual, alat dan media belajar mengandalkan teknologi. Saat dimana kondisi pandemic terjadi dalam kurun waktu yang lama, kebosanan dan kelelahan tak lagi dapat dihindarkan, maka motivasi dan semangat belajar menjadi pokok perhatian. Oleh sebab itu, SMA Tarakanita Citra Raya berupaya menghadirkan pengalaman belajar berbeda dari biasanya dengan membuat program "Guru Tamu" salah satunya menghadirkan dosen untuk mengajar. Matematika merupakan pelajaran yang tidak disukai oleh sebagian besar siswa, hal ini terjadi juga di SMA Tarakanita Citra Raya untuk mata pelajaran matematika khususnya pada pokok bahasan Trigonometri. Oleh karena itu penyelesaian permasalahan dilakukan dengan cara menawarkan pengabdian kepada masyarakat dengan mengajar matematika. Kegiatan ini bertujuan memberikan pengalaman baru bagi siswa dan membuat siswa menjadi lebih tertarik belajar matematika khususnya Trigonometri. Metode yang digunakan adalah pembelajaran Brain Based Learning ditekankan pada Student Center dan memaparkan penjelasan mengenai konsep dasar asal mula rumus trigonometri dan aplikasinya dalam kehidupan sehari-hari diberbagai bidang disiplin ilmu sehingga membuat siswa menjadi lebih tertarik, motivasi belajar siswa semakin meningkat. Hal ini ditunjukkan banyaknya jumlah peserta yang melebihi kapasitas zoom sehingga diawal mau dimulainya acara ini sempat ada sedikit kendala teknis. Tetapi, secara keseluruhan program yang direncanakan
\end{abstract}


dapat terlaksana semua dengan lancar. Selain siswa lebih tertarik, penalaran dan proses berpikir siswa semakin meningkat. Hal ini ditunjukkan dengan banyaknya siswa yang antusias bertanya dan menyampaikan temuan pengalamannya yang sesuai dengan implementasi konsep trigonometri.

Kata kunci: mengajar, matematika, trigonometri dan penerapannya

\section{PENDAHULUAN}

\section{Analisis situasi}

Kegiatan pengabdian kepada masyarakat seminar online ini bekerja sama dengan SMA Tarakanita Citra Raya yang berlokasi J1. Citra Raya Timur 2 Blok L3 Ciakar, Kec. Panongan, Kab. Tangerang, Prov. Banten. SMA Tarakanita Citra Raya berdiri pada Tahun 2009 di bawah Yayasan Tarakanita Indonesia yang merupakan SMA yang ke-13. Sebagai sekolah yang baru berkembang dikawasan Citra Raya - Tangerang Banten, dalam usianya yang relatif muda SMA Tarakanita Citra Raya telah menunjukkan daya tarik yang luar biasa bagi masyarakat setempat dengan dibuktikan jumlah calon siswa yang melebihi kapasitas kelas yang hanya menerima 2 kelas pada setiap tahun pembelajaran.

SMA Tarakanita Citra Raya dengan mengedepankan visi misi sekolah yang menjujung tinggi harkat dan martabat manusia, dengan pengembangan pendidikan dari sisi akademik dan non akademik serta membentuk karakter yang baik dan professional. Berdasarkan rumusan visi dan misi SMA Tarakanita Citra Raya mengupayakan terbentuknya manusia berprestasi yang kompetitif dan berkepribadian utuh. Setiap peserta didik SMA Tarakanita Citra Raya dibentuk untuk menjadi manusia dengan keunggulan nilai Comppassion, Celebration, Competence, Creativity, Conviction, dan Community. Nilai-nilai yang senantiasa dihidupi dalam pelayanan Pendidikan SMA Tarakanita Citra Raya yang lebih dikenal dengan istilah Cc5.

Pandemi covid-19 telah mengubah berbagai segi kehidupan, tidak terkecuali dunia Pendidikan. Proses pembelajaran di sekolah tidak dapat dilaksanakan, semua beralih ke pembelajaran jarak jauh, interaksi tatap muka langsung berubah menjadi virtual, alat dan media belajar mengandalkan teknologi, sedang kegiatan ekstrakurikuler tidak bisa lagi terfasilitasi. Disatu sisi, pandemi menghadirkan begitu banyak persoalan, tetapi disisi lain pandemi memberi ruang kreasi dan inovasi bagi sekolah, para guru, juga peserta didik dalam memberikan dan mengikuti layanan pembelajaran.

SMA Tarakanita Citra Raya sebagai Lembaga Pendidikan begerak cepat mencari dan menemukan terobosan-terobosan guna merancang pembelajaran di masa pandemi. Insight dari pengalaman masa pendemi tidak lain adalah bagaimana menjadi kreatif mengelola pembelajaran, meletakkan materi ajar sesuai dengan kebutuhan, menghadirkan tema-tema kontekstual sebagai bagian dari proses membekali peserta didik dengan nilai-nilai keterampilan dan karakter yang dibutuhkan sesuai situasi dan kondisi riil.

Menarik dan menyenangkan adalah kunci keberhasilan pengelolaan pembelajaran di masa krisis, saat dimana kondisi pandemi terjadi dalam kurun waktu yang lama, kebosanan dan kelelahan tak lagi dapat dihindarkan, maka motivasi dan semangat belajar menjadi pokok perhatian. Oleh sebab itu, SMA Tarakanita Citra Raya berupaya menghadirkan pengalaman belajar yang berbeda dari yang biasanya. Sudah semestinya pembelajaran mewadahi berbagai kebutuhan baik pengetahuan, keterampilan, maupun sikap, tetapi sering kali terjadi bahwa materi ajar dan tuntutan kurikulum tidak memberikan porsi yang cukup terhadap keseimbangan ketiganya terhadap materi-materi yang relevan dengan situasi dan kondisi aktual. Sedemikian sehingga perlunya pembelajaran dibawa ke luar kelas, dihadapkan pada konteks dan permasalahanpermasalahan riil, sehingga peserta didik dibiasakan untuk menjadi pribadi yang kritis dan problem solver, menemukan berbagai setrategi pemecahan masalah. Tidak cukup hanya di bawa 
keluar kelas dan tidak cukup hanya dari guru, peserta didik juga perlu mendapatkan ilmu dari orang-orang yang karena pengalamannya, keterampilannya, maupun perilakunya menjadi orangorang yang sukses sesuai bidang masing-masing. Hal inilah yang melatarbelakangi dibuatnya program "Guru Tamu” yang salah satunya menghadirkan dosen untuk mengajar matematika.

Mata pelajaran matematika merupakan mata pelajaran yang wajib diberikan diseluruh jenjang persekolahan dari sejak sekolah dasar sampai menengah atas, materi atau bahan ajarnya disesuaikan dengan tahap perkembangan dan pertumbuhan peserta didik (siswa). Dalam perkembangan ilmu pengetahuan dewasa ini, matematika dapat dikatakan sebagai ilmu dasar untuk menguasai berbagai macam ilmu pengetahuan, karena tanpa berpikir logis, kritis dan analisis dalam dunia ilmu pengetahuan, kecil kemungkinan tidak akan maju perkembangan ilmu pengetahuan dan teknologi. Apalagi dalam dunia kehidupan sehari-hari, matematika tidak akan mungkin lepas dari hidup dan kehidupan. Namun kenyataan dilapangan atau sekolah-sekolah, matematika nampaknya menjadi mata pelajaran yang paling tidak disukai oleh sebagian besar siswa, hal ini juga terjadi di SMA Tarakanita Citra Raya untuk mata pelajaran matematika khususnya pada pokok bahasan Trigonometri. Oleh sebab itu maka perlu diadakan seminar dengan tema "Trigonometri dan Aplikasi nya dalam Kehidupan Sehari-hari".

\section{Masalah mitra dan solusinya}

Berdasarkan analisis situasi bahwa persepsi siswa yang menganggap matematika sulit khususnya trigonometri dan metode pembelajaran yang bersifat satu arah selama proses belajar yaitu model pembelajaran dengan lebih banyak mendengarkan materi oleh guru yang ada dalam kelas online merupakan kendala dalam siswa memahami dan menguasai materi trigonometri. Selain itu, tidak adanya contoh manfaat aplikasi/peranan trigonometri dalam berbagai bidang disiplin ilmu dalam kehidupan sehari-hari membuat rendahnya minat dan kurang bersemangatnya siswa dalam mempelajari trigonometri.

Berdasarkan identifikasi permasalahan yang dihadapi mitra, siswa pada tingkatan SMA rata-rata berada pada usia antara 15-19 tahun dan tergolong pada masa remaja madya. Berdasarkan tingkat perkembangan intelektual Piaget, anak SMA berada pada tingkat formal yaitu anak dapat menggunakan operasi konkret untuk membentuk operasi yang lebih kompleks, merumuskan hipotesis, mengkombinasikan gagasan, proporsi yang mungkin, dan berpikir reflektif yaitu berpikir tentang berpikirnya yang termasuk kemampuan metakognisi (Ratna Wilis Dahar, 2006). Selanjutnya, Piaget (Upton, 2012) menyatakan pada tahap formal, siswa mampu menyelesaikan masalah abstrak secara logis yang dipengaruhi oleh otak dalam memproses pemikiran. Oleh karena itu penyelesaian permasalahan dilakukan dengan cara menawarkan seminar dengan tema "Trigonometri dan Aplikasinya dalam Kehidupan Sehari-hari" pada siswa-siswi SMA Tarakanita Citra Raya yang dikemas dengan metode pembelajaran Brain Based Learning ditekankan pada Student Center. Kelebihan model Brain Based Learning adalah motivasi belajar siswa semakin meningkat, penalaran dan proses berpikir siswa semakin meningkat, dan siswa dapat menghubungkan pengalamannya dengan materi yang sedang dipelajari.

\section{METODE PELAKSANAAN PKM}

\section{Khalayak sasaran}

Khalayak sasaran kegiatan mengajar dalam rangka memberikan pengalaman baru bagi siswa dan membuat siswa menjadi lebih tertarik belajar matematika khususnya Trigonometri adalah siswasiswi kelas $X$ dan XI SMA Tarakanita Citra Raya. Kegiatan dilaksanakan secara daring dengan jumlah khalayak sasaran 102 siswa. Adapun yang menjadi operator adalah mahasiswa anggota 
pengabdian kepada masyarakat dan yang menjadi narasumber adalah dosen matematika Universitas Tarumanagara yang ahli dan berpengalaman dalam pembelajaran matematika.

\section{Metode kegiatan}

Untuk memecahkan masalah yang sudah diidentifikasi dan dirumuskan tersebut di atas, agar pengajaran matematika dapat berjalan dengan lancar maka sebagai alternatif pemecahan masalah adalah sebagai berikut: pengajaran dilakukan dengan pendekatan individual dan klasikal. Pendekatan klasikal dilakukan pada saat pemberian teori tentang konsep trigonometri dan pendekatan individual dilakukan pada saat tanya jawab terkait aplikasi trigonometri dalam kehidupan sehari-hari. Adapun metode yang digunakan adalah:

a. Ceramah Bervariasi

Metode ini dipilih untuk menyampaikan konsep-konsep yang penting untuk dimengerti dan dikuasai oleh peserta seminar. Penggunaan metode ini dengan pertimbangan bahwa metode ceramah yang dikombinasikan dengan gambar-gambar, animasi dan display dapat memberikan materi yang relatif banyak secara padat, cepat dan mudah.

b. Brain Based Learning

Metode pembelajaran Brain Based Learning ditekankan pada Student Center. Kelebihan model Brain Based Learning adalah motivasi belajar siswa semakin meningkat, penalaran dan proses berpikir siswa semakin meningkat, dan siswa dapat menghubungkan pengalamannya dengan materi yang sedang dipelajari.

c. Tanya Jawab

Metode ini digunakan untuk memungkinkan terjadinya komunikasi langsung yang bersifat dua arah sehingga ada hubungan timbal balik sehingga dapat merangsang minat dan motivasi siswa dalam belajar matematika trigonometri.

\section{Langkah-langkah kegiatan}

Adapun langkah-langkah kegiatan yang dilakukan adalah pengajaran secara daring dengan tahapan sebagai berikut:

a. Ceramah tentang sejarah trigonometri

b. Ceramah tentang teori sudut

c. Ceramah tentang perbandingan trigonometri dan nilainya untuk sudut istimewa

d. Ceramah tentang konsep perbandingan trigonometri untuk sudut yang berelasi

e. Ceramah tentang konsep identitas, jumlah selisih, perkalian dan sudut ganda trigonometri

f. Ceramah tentang aplikasi trigonometri dalam kehidupan sehari-hari diberbagai bidang disiplin ilmu

g. Mengarahkan siswa untuk menghubungkan pengalamannya dengan materi yang sudah dipelajari

h. Memberikan kesempatan kepada siswa untuk bertanya.

\section{Faktor pendukung dan penghambat}

Berdasarkan evaluasi pelaksanaan dan hasil kegiatan dapat diidentifikasi factor pendukung dan penghambat dalam melaksanakan program pengabdian pada masyarakat ini. Secara garis besar faktor pendukung dan penghambat tersebut adalah sebagai berikut:

a. Faktor Pendukung

1. Tersedianya tenaga ahli yang memadai dalam pengajaran matematika di Fakultas Teknologi Informasi Universitas Tarumangara

2. Antusiasme para siswa yang cukup tinggi terhadap pengajaran matematika trigonometri dan aplikasinya dalam kehidupan sehari-hari, karena ternyata masih banyak siswa yang belum mengetahui penerapan matematika trigonometri. 
3. Dukungan kepala sekolah SMA Tarakanita Citra Raya yang menyambut baik pelaksanaan kegiatan pengajaran matematika trigonometri dan aplikasi dalam kehidupan sehari-hari dan membantu tim pengabdi mengorganisasikan waktu dan media pelaksanaan kegiatan.

4. Ketersediaan dana pendukung dari Lembaga Penelitian dan Pengabdian Kepada Masyarakat Universitas Tarumanagara guna penyelenggaraan kegiatan pengabdian pada masyarakat ini.

\section{b. Faktor Penghambat}

1. Siswa peserta pengajaran masih banyak yang belum memiliki pengetahuan tentang asal mula rumus trigonometri dan aplikasinya dalam kehidupan sehari-hari

2. Keterbatasan waktu untuk pelaksanaan pengajaran sehingga beberapa materi tidak dapat disampaikan secara detail

3. Daya tangkap para peserta yang bervariasi, ada yang cepat namun juga ada yang lambat sehingga waktu yang digunakan kurang maksimal

\section{HASIL DAN PEMBAHASAN}

Kegiatan pengabdian kepada masyarakat yang dilaksanakan dengan seminar secara daring dan tanya jawab berjalan dengan baik dan lancar. Pertemuan daring dengan metode ceramah dan Brain Based Learning ditekankan pada Student Center, dilanjutkan tanya jawab untuk aplikasi trigonometri dalam kehidupan sehari-hari, mulai dari pemilihan materi, penyusunan, pemilihan huruf, pemberian efek dan animasi dan tampilan. Kegiatan ini dilaksanakan sehari yaitu pada hari Senin tanggal 08 Maret 2021 dari pukul 10.30-13.30 WIB. Peserta kegiatan berjumlah 102 orang siswa SMA Tarakanita Citra Raya dari jurusan IPA dan media yang digunakan adalah aplikasi Zoom.

Pelaksanaan kegiatan pengabdian kepada masyarakat ini dilakukan oleh 4 (empat) orang tim pengabdi dengan pokok bahasan yang disampaikan mengenai:

1. Sejarah Trigonometri

2. Sudut

3. Perbandingan Trigonometri dan Nilainya untuk Sudut Istimewa

4. Konsep Perbandingan Trigonometri untuk Sudut yang Berelasi

5. Konsep Identitas, Jumlah Selisih, Perkalian dan Sudut Ganda Trigonometri

6. Aplikasi Trigonometri dalam Kehidupan sehari-hari di berbagai bidang disiplin ilmu. Keterbatasan waktu pertemuan mengakibatkan tidak semua materi dapat disampaikan dengan detil.

Kegiatan yang diawali dengan ceramah dan Brain Based Learning ditekankan pada Student Center kemudian dilanjutkan tanya jawab. Dari kegiatan mengajar tampak bahwa siswa memang belum mengetahui aplikasi trigonometri dalam berbagai bidang disiplin ilmu, khususnya dalam kehidupan sehari-hari. Acara kemudian dilanjutkan sesi tanya jawab. Berbagai pertanyaan diajukan secara antusias oleh para peserta dalam sesi tanya jawab. Secara garis besar inti dari pertanyaan para peserta adalah:

1. Kesulitan dalam memahami konsep trigonometri

2. Penerapan trigonometri dalam kehidupan sehari-hari

3. Kiat-kiat suapaya mudah memahami dan menguasai trigonometri

Program pengabdian pada masyarakat berupa mengajar matematika trigonometri dan aplikasinya dalam kehidupan sehari-hari bagi siswa-siswi SMA Tarakanita Citra Raya yang sudah dilaksanakan ini diharapkan dapat menambah pengetahuan, keterampilan dan lebih percaya diri 
dalam mempelajari matematika. Siswa akan lebih semangat dan termotivasi untuk belajar matematika. Hasil program mengajar ini akan bermanfaat bagi sekolah, proses belajar mengajarnya akan lebih menarik dengan digunakannya model pembelajaran yang lebih bervariasi. Disamping itu dengan adanya program mengajar oleh dosen ini akan menambah pengetahuan siswa dalam hal konsep trigonometri sehingga akan mendukung kemampuan siswa dalam menyelesaikan soal-soal trigonometri.

Hasil kegiatan pengabdian kepada masyarakat secara garis besar mencakup beberapa komponen sebagai berikut:

1. Keberhasilan target jumlah peserta

2. Ketercapaian tujuan mengajar

3. Ketercapaian target materi yang telah direncanakan

4. Kemampuan peserta dalam penguasaan materi

Target peserta program mengajar seperti direncanakan sebelumnya adalah paling tidak 100 siswa SMA Tarakanita Citra Raya. Dalam pelaksanaannya, kegiatan ini diikuti oleh 102 orang peserta. Dengan demikian dapat dikatakan bahwa target peserta tercapai 100\%. Angka tersebut menunjukkan bahwa kegiatan pengabdian kepada masyarakat dilihat dari jumlah peserta yang mengikuti dapat dikatakan berhasil/ sukses.

Ketercapaian tujuan program mengajar matematika trigonometri dan aplikasinya dalam kehidupan sehari-hari secara umum sudah baik, namun keterbatasan waktu yang disediakan mengakibatkan tidak semua materi tentang konsep trigonometri dan aplikasinya dalam kehidupan sehari-hari dapat disampaikan secara detail. Namun dilihat dari hasil tanya jawab para peserta yaitu kualitas jawaban pertanyaan yang disampaikan, maka dapat disimpulkan bahwa tujuan kegiatan ini dapat tercapai.

Kemampuan peserta dilihat dari penguasaan materi masih kurang dikarenakan waktu yang singkat dalam penyampaian materi dan kemampuan para peserta yang berbeda-beda. Hal ini disebabkan jumlah materi yang banyak hanya disampaikan dalam waktu sehari sehingga tidak cukup waktu bagi para peserta untuk memahami dan latihan secara lengkap semua materi yang diberikan.

Secara keseluruhan kegiatan program mengajar matematika trigonometri dan aplikasinya dalam kehidupan sehari-hari untuk memberikan pengalaman baru bagi siswa dan membuat siswa menjadi lebih tertarik belajar matematika khususnya Trigonometri dapat dikatakan berhasil. Keberhasilan ini selain diukur dari keempat komponen di atas, juga dapat dilihat dari kepuasan peserta setelah mengikuti kegiatan. Manfaat yang diperoleh siswa adalah dapat memahami konsep trigonometri dan aplikasinya dalam kehidupan sehari-hari dan diharapkan pemahaman tersebut sudah memenuhi capaian pembelajaran yang di targetkan untuk dapat dipakai sebagai poin dalam penilaian akhir semester. 


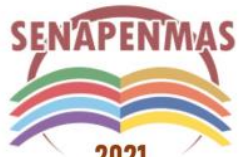

2021
Seminar Nasional Hasil Penelitian dan Pengabdian Kepada Masyarakat 2021 Pengembangan Ekonomi Bangsa Melalui Inovasi Digital Hasil Penelitian dan Pengabdian Kepada Masyarakat Jakarta, 21 Oktober 2021

\section{KESIMPULAN}

Pelaksanaan mengajar di SMA Tarakanita Citra Raya sebagai wujud kegiatan Pengabdian Kepada Masyarakat (PKM) memberikan pandangan dan pengalaman baru bagi siswa, biasanya siswa hanya menghafal rumus dan menyelesaikan contoh soal tetapi dalam kegiatan mengajar kali ini dikemas dengan metode pembelajaran Brain Based Learning ditekankan pada Student Center dan memaparkan penjelasan mengenai konsep dasar asal mula rumus trigonometri dan aplikasinya dalam kehidupan sehari-hari diberbagai bidang disiplin ilmu membuat siswa menjadi lebih tertarik, motivasi belajar siswa semakin meningkat. Hal ini ditunjukkan banyaknya jumlah peserta yang melebihi kapasitas zoom sehingga diawal mau dimulainya acara ini sempat ada sedikit kendala teknis. Tetapi, secara keseluruhan program yang direncanakan dapat terlaksana semua dengan lancar.

Selain siswa lebih tertarik, penalaran dan proses berpikir siswa semakin meningkat, pemahaman konsep trigonometri siswa juga lebih kuat karena mengetahui asal mula rumus dan mengetahui dapat digunakan untuk apa trigonometri dalam kehidupan sehari-hari diberbagai bidang disiplin ilmu, sehingga siswa dapat menghubungkan pengalamannya dengan materi yang sedang dipelajari. Hal ini ditunjukkan dengan banyaknya siswa yang antusias bertanya dan menyampaikan temuan pengalamannya yang sesuai dengan implementasi konsep trigonometri.

\section{REFERENSI}

Agustina, L. Roesdiana, L. dan Imami, I.A. 2018. Implementasi Model Brain Based Learning dalam Meningkatkan Kemampuan Penalaran Matematis Siswa SMA. Seminar Nasional Matematika dan Pendidikan Matematika. 13 September 2019, Tangerang, Indonesia. pp. $410-424$

Gumilang, A. 2016. Keefektifan Pendekatan Brain Based Learning Terhadap Kemampuan Berpikir Kreatif Matematik Siswa SMA Kelas X. Jurusan Matematika Fakultas Matematika dan Ilmu Pengetahuan Alam Universitas Negeri Semarang.

Lestari, A. Rahayu, W. dan Sampoerno, D.P. 2021. Pengaruh Model Brain Based Learning Terhadap Kemampuan Koneksi Matematis Siswa SMA ditinjau dari Self Regulated Learning. Jurnal Riset Pembelajaran Matematika Sekolah. 5 (1): 28 - 37.

Prastuti, D.E. Mardiyana dan Pambudi, D. 2019. Penerapan Model Brain Based Learning (BBL) Pada Pembelajaran Matematika Untuk Meningkatkan Ketuntasan dan Aktivitas Belajar Siswa. Jurnal Pendidikan Matematika dan Matematika SOLUSI. 3 (1): 10 - 18.

Purnamawati. 2018. Pembelajaran Matematika dengan Strategi Brain Based Learning dan Problem Based Learning terhadap Hasil Belajar Matematika Ditinjau dari Kemandirian Siswa. Program Studi Pendidikan Matematika Fakultas Keguruan dan Ilmu Pendidikan Universitas Muhammadiyah Surakarta.

Sukoco, H dan Mahmudi, A. 2016. Pengaruh Pendekatan Brain Based Learning terhadap Kemampuan Komunikasi Matematis dan Self-Efficacy Siswa SMA. Pythagoras: Jurnal Pendidikan Matematika. 11 (1): 11 - 24.

Sulyono, K. 2008. Pembelajaran Trigonometri SMA. Pusat Pengembangan dan Pemberdayaan Pendidik dan Tenaga Kependidikan Matematika. Yogyakarta.Indonesia

Syarah, S.P . 2011. IM-1 Intisari Matematika 1 untuk SMA/MA Kelas X. Andi . Yogyakarta. Indonesia.

Syarah, S.P . 2011. IM-2 Intisari Matematika 2 untuk SMA/MA Kelas XI. Andi . Yogyakarta. Indonesia.

Tampomas H. 2007. Seribu Pena Matematika untuk SMA/MA Kelas XI. Erlangga. Jakarta. Indonesia. 
Seminar Nasional Hasil Penelitian dan Pengabdian Kepada Masyarakat 2021

Pengembangan Ekonomi Bangsa Melalui Inovasi Digital Hasil Penelitian dan

Pengabdian Kepada Masyarakat

Jakarta, 21 Oktober 2021

(halaman kosong) 